\title{
Physical Land Suitability Evaluation for Irrigation in the Lower Alwero River Area of Abobo, Western Ethiopia
}

\author{
Teshome Yitbarek ${ }^{1,}$, Kibebew Kibret ${ }^{2}$, Shelem Beyene ${ }^{3}$ \\ ${ }^{1}$ Department of Natural Resource Management, College of Agriculture and Natural Resource, Wolkite University, Wolkite, Ethiopa \\ ${ }^{2}$ School of Natural Resources and Environmental Science, College of Agriculture and Environmental Science, Haramaya University, Dire \\ Dawa, Ethiopia \\ ${ }^{3}$ Department of Plant and Horticultural Science, College of Agriculture, Hawassa University, Hawassa, Ethiopia
}

\section{Email address:}

teshome.yitbarek@wku.edu.et (Teshome Y.), kibebewkibrett@yahoo.com (Kibebew K.), shelemebe@yahoo.com (Sheleme B.)

\section{To cite this article:}

Teshome Yibarek, Kibebew Kibret and Sheleme Beyene. Physical Land Suitability Evaluation for Irrigation in the Lower Alwero River Area of Abobo, Western Ethiopia. American Journal of Agriculture and Forestry. Vol. 5, No. 3, 2017, pp. 60-64.

doi: 10.11648/j.ajaf.20170503.14

Received: August 3, 2013; Accepted: January 10, 2017; Published: May 9, 2017

\begin{abstract}
Land suitability assessment plays an important role in identifying biophysical constraints and evaluating potential capacity of land and its sustainable use. Physical land suitability evaluation for irrigation was carried out in the lower Alwero river area of Abobo, western Ethiopia, following FAO methodology for general irrigation farming. The irrigation suitability of five land mapping units (LMUs): $1 \mathrm{Ac}, 1 \mathrm{Bc}, 1 \mathrm{Ecl}, 2 \mathrm{Cc}$ and $3 \mathrm{Ccl}$ were assessed by considering slope, drainage, top soil texture, sub soil texture, surface stoniness, surface coarse fragments, subsurface coarse fragment, rockiness, depth to solid rock or hardpan, lime, gypsum, electrical conductivity (EC) and exchangeable sodium percentage (ESP). The result revealed that LMU $1 \mathrm{Ac}, 1 \mathrm{Bc}$ and $2 \mathrm{Cc}$, with total area of 22,367.9 ha (83.7\%), were moderately suitable (S2). The moderate limiting factors were drainage, top soil texture and subsoil texture. On the other hand, LMU 1Ec1, covering an area of 3,677.6 ha $(13.8 \%)$ was not suitable $(\mathrm{N})$ for irrigation due to subsurface coarse fragments and depth to solid rock or hardpan. For all LMUs, parameters like lime, gypsum, EC and ESP were not considered as limiting factors.
\end{abstract}

Keywords: Irrigation Suitability, Land Mapping Unit, Limiting Factor

\section{Introduction}

Assessment of irrigation potential has prime importance for planning of sustainable food production. Irrigation is viewed as a key factor in progress towards achieving food security in Africa. However, while nearly $40 \%$ of the world's agricultural production comes from irrigated land [1], only 4 per cent (6 million ha) of the sub-Saharan African total cultivated area is irrigated. [2]. Virtually all food crops production in Ethiopia come from rainfed agriculture with the irrigation subsector accounting for only about $3 \%$ of the food crops production [3]. Irrigation of additional lands is, however, a strategic necessity for the food security in the world [4]. Therefore, assessment of soil and terrain suitability for irrigation is imperative.

Land suitability assessment plays an important role in maintaining and developing land use on a spatial basis. It identifies the levels and geographical patterns of biophysical constraints and evaluates potential capacity of land and its sustainable use. Sustainable management of land resource requires sound policies and planning based on knowledge of these resources. So it is very important for agriculture development planning to take land resources assessment [5]. On the other hand, inappropriate land use leads to inefficient exploitation of natural resources, destruction of the land resource, poverty and other social problems. Part of the solution to the land-use problem is land evaluation in support of rational land-use planning and appropriate and sustainable use of natural resources [6]. The land use planning involves making knowledgeable decisions about land use and the environment [7].

Limits to the productive capacity of land resources are set by climate, soil and land form conditions and by the use and management applied to the land [5]. The soil characteristics are the result of pedogenesis factors and processes, which 
influence their physical and chemical properties, and most importantly movement and storage of water in the soil. Assessment of soil potential for irrigation include slope, top soil texture, sub soil texture, surface stoniness, surface coarse fragments, subsurface coarse fragment, rockiness, depth to solid rock or hardpan, lime content, gypsum content, electric conductivity (EC) and exchangeable sodium percentage (ESP) [8].

Ethiopia has a significant irrigation potential identified from both available land and water resources. The total potential irrigable land in Ethiopia is estimated to be around 3.7 million hectares [9] and the potential land for irrigation development in Gambella region, where the present study was conducted, is estimated to be 500,000 ha [10]. The region has a number of perennial rivers including, Baro, Alwero, Gillo and Akobo, which can be used as potential source of irrigation water. Currently, forest land has been changed to rainfed and irrigation land due to agricultural expansion and investment regardless of irrigation suitability assessment in the study area, which may in turn leads to inappropriate land use. To use the land in an optimum way and in a sustainable manner, land suitability evaluation for irrigation is a prerequisite. Taking into account this fact, this study was initiated and carried out to assess the physical land suitability for irrigation in the lower Alwero river area of Abobo, western Ethiopia.

\section{Materials and Methods}

\subsection{Description of the Study Area}

The study area, Abobo District, is located at $42 \mathrm{~km}$ south of Gambella town and about $808 \mathrm{~km}$ from Addis Ababa in the western direction. It lies between $07^{\circ} 50^{\prime} 47.3^{\prime \prime}$ to $08^{\circ} 01^{\prime}$ $59.3^{\prime \prime} \mathrm{N}$ and $34^{\circ} 28^{\prime} 59.5^{\prime \prime}$ to $34^{\circ} 34^{\prime} 37.1^{\prime \prime}$ E. The altitude of the study area ranges from 446 to 490 meter above sea level (masl) with slope ranging from level $(0.2-0.5 \%)$ to gently sloping (2-5\%).

The climate of the region is influenced by the tropical monsoon which is characterized by high rainfall in the wet period from May to October and has little rainfall during the dry period from November to April [10]. The mean minimum monthly temperature of the area varies from 16.2 to $21.2^{\circ} \mathrm{C}$ and the mean maximum monthly temperature ranges from 32.1 to $38.2^{\circ} \mathrm{C}$, whereas the average annual rainfall is $955.5 \mathrm{~mm}$ (Figure 2). The region is drained by a number of perennial rivers including, Baro, Alwero, Gillo and Akobo and their tributaries.

The geology of Abobo is characterized by undifferentiated Pleistocene Holocene deposits. Granite, gneisses, schist, sandstone and basalt are the rock types existed in the region [11]. The major soils of Abobo District include Dystric and Eutric Plinthosols, Dystric and Chromic Cambisols, Eutric Vertisols and Planosols, where Cambisols occur at the upper slope north of Abobo while Plinthosols and Vertisols exist at the middle and lower slopes, respectively [10].

The Abobo district encompasses forest land, wood land, shrub land, grass land and cultivated lands occupying, $143,086,75,227,5,793,62,997$ and 19,854 hectares (ha), respectively [12]. The forest cover is continuously declining due to settlement and agricultural expansion. The major crops grown by farmers include maize (Zea mays L.), sorghum (Sorghum bicolor), groundnut (Arachis hypogae) and sesame (Sesamum astivum), whereas cotton (Gossypium sp.) and rice (Oryza sativa L.) are cultivated by state farms and investors operating at and around the study area.

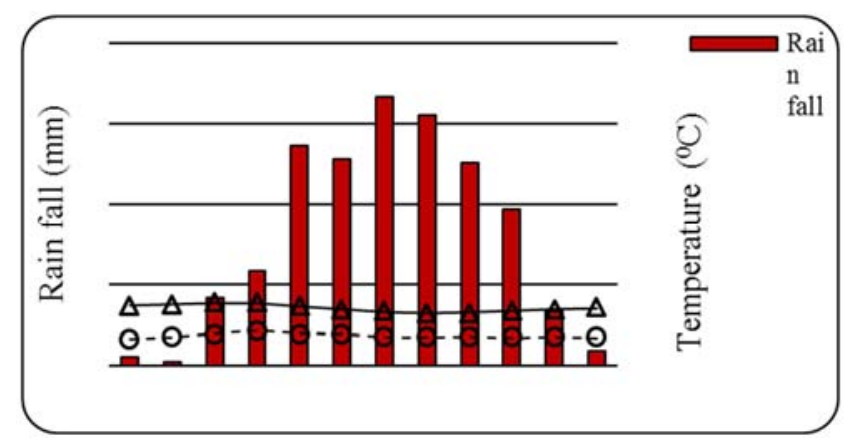

Figure 1. Mean monthly rainfall, and monthly minimum (Min) and maximum (Max) temperatures of Abobo area for the years 1975 to 2011.

\subsection{Class Determining Factors for the Evaluation}

As depicted in Table 1, the class determining factors for the evaluation were slope $(\%)$, drainage, top soil texture $(0-25 \mathrm{~cm})$, sub soil texture $(25-100 \mathrm{~cm})$, surface stoniness $(\%)$, surface coarse fragments $(0-25 \mathrm{~cm})(\%)$, subsurface coarse fragment $(25-100 \mathrm{~cm})(\%)$, rockiness $(\%)$, depth to solid rock or hardpan $(\mathrm{m})$, lime content $(\%)$, gypsum content (\%), EC mmhos $/ \mathrm{cm}$ (average 0-100 cm) and ESP (maximum $0-100 \mathrm{~cm})[8,13]$.

Table 1. Factor ratings for irrigation suitability.

\begin{tabular}{|c|c|c|c|c|}
\hline \multirow{2}{*}{ Class determining factors } & \multicolumn{4}{|c|}{ Factor ratings } \\
\hline & S1 & S2 & S3 & $\mathbf{N}$ \\
\hline Slope $(\%)$ & $<2$ & $<5$ & $<8$ & $<25$ \\
\hline Drainage & Moderate & Slow to somewhat rapid & Slow to rapid & Very slow to very rapid \\
\hline Top soil texture $(0-25 \mathrm{~cm})$ & SL to $C L$ & LS to $\mathrm{C}-60 \mathrm{v}$ & $\mathrm{S}$ to $\mathrm{C}+60 \mathrm{v}$ & $\mathrm{Sc}$ to $\mathrm{Cm}$ \\
\hline Sub soil texture $(25-100 \mathrm{~cm})$ & fSL to CL & LfS to C-60v & $\mathrm{LmS}$ to $\mathrm{C}+60 \mathrm{v}$ & $\mathrm{Sc}$ to $\mathrm{Cm}$ \\
\hline Surface stoniness $(\%)$ & none & $<0.1$ & $0.1-3$ & $3-15$ \\
\hline Surface coarse fragments $(0-25 \mathrm{~cm})(\%)$ & $<3$ & $3-15$ & $15-35$ & $<35$ \\
\hline Subsurface coarse fragment $(25-100 \mathrm{~cm})(\%)$ & $<15$ & $15-35$ & $35-55$ & $55-75$ \\
\hline
\end{tabular}




\begin{tabular}{|c|c|c|c|c|}
\hline \multirow{2}{*}{ Class determining factors } & \multicolumn{4}{|c|}{ Factor ratings } \\
\hline & S1 & S2 & S3 & $\mathbf{N}$ \\
\hline Rockiness (\%) & $0 \%$ & $0-2$ & $2-10$ & $10-25$ \\
\hline Depth to solid rock or hardpan (m) & $>2$ & $1.5-2$ & $1-1.5$ & $0.25-1$ \\
\hline Lime content $(\%)$ & $<15$ & $15-25$ & $25-40$ & $40-75$ \\
\hline Gypsum content (\%) & $<5 \%$ & $15 \%$ & $<30$ & $<30$ \\
\hline EC mmhos/cm (average $0-100 \mathrm{~cm}$ ) & $<4$ & $4-8$ & $8-16$ & $16-30$ \\
\hline ESP \% (maximum $0-100 \mathrm{~cm}$ ) & $<5$ & $5-15$ & $15-25$ & $25-45$ \\
\hline
\end{tabular}

Source: Sys et al. (1991b), FAO (1985)

CL: clay loam; C+60s: very fine clayey; SC: sand clay; C-60v: clay; vertic; Lfs: loamy fine sand; fSL: fine sandy loam; LS: loamy sand; Cm: massive clay; SiCm: massive silty clay; $\mathrm{S}$ : sand.

\subsection{Description and Characterization of Land Mapping \\ Unit}

Identification of the land mapping units (LMUs) was based on slope, soil depth and soil texture. The entire study area was categorized into three slopes, four soil depths and two textural classes. Seven representative pedons (A-1 to A-7) were opened across the study area. The pedons were classified according to WRB [14] as Haplic Cambisols, Vertic Luvisols, Mollic Leptosols and Mollic Vertisols (Table 1). The pedons were further categorized into five LMUs: $1 \mathrm{Ac}, 1 \mathrm{Bc}, 1 \mathrm{Ecl}, 2 \mathrm{Cc}$ and $3 \mathrm{Ccl}$ (Figure 2) for the purpose of land suitability evaluation. The first number and the last small letter in the LMU designation indicate the slope and texture, respectively, whereas the middle capita letter indicates the soil depth. The slope categories were 1(0-1), 2 (1-2), 3 (2-5). There were two texture categories: c (clay) and cl (clay loam). There were four depth categories: A $(>150 \mathrm{~cm})$, B $(100-150 \mathrm{~cm})$, C $(50-100 \mathrm{~cm})$, E $(<30 \mathrm{~cm})$ (Table 2).

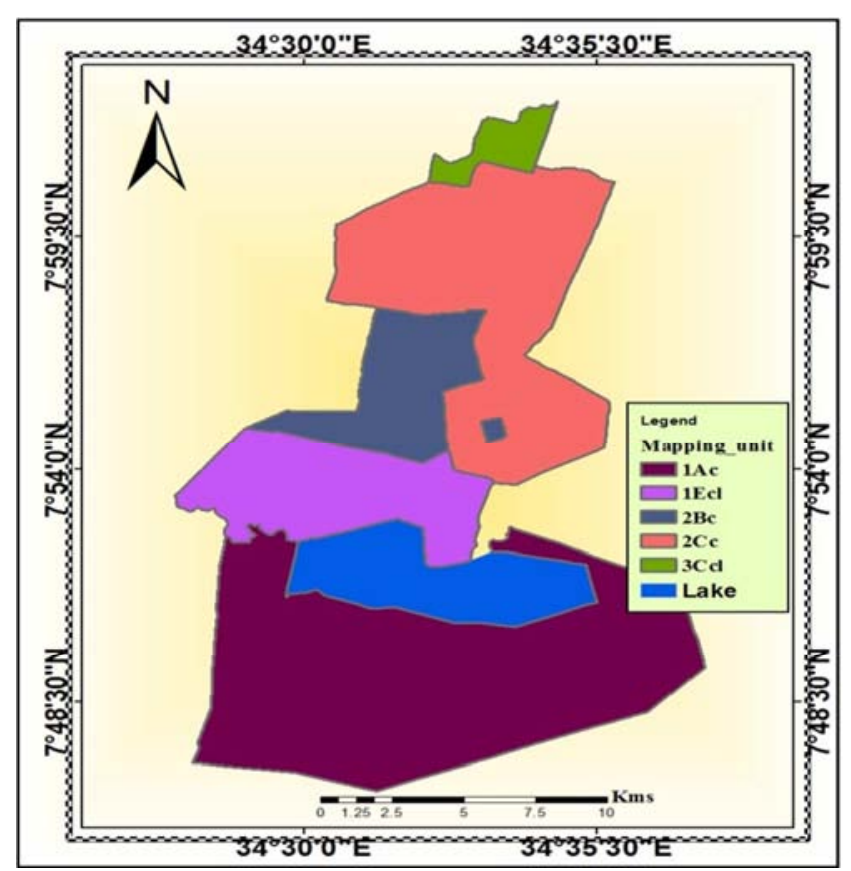

Figure 2. Mapping units of the study area.

Table 2. The identified mapping units and their area coverage in the soils of Abobo area.

\begin{tabular}{|c|c|c|c|c|c|c|}
\hline \multirow{2}{*}{$\begin{array}{l}\text { Map- } \\
\text { ping } \\
\text { unit }\end{array}$} & \multirow{2}{*}{$\begin{array}{l}\text { Slope } \\
\text { (\%) }\end{array}$} & \multirow{2}{*}{$\begin{array}{l}\text { Soil } \\
\text { depth } \\
\text { (cm) }\end{array}$} & \multirow[b]{2}{*}{$\begin{array}{l}\text { Tex- } \\
\text { ture }\end{array}$} & \multicolumn{2}{|l|}{ Area } & \multirow[b]{2}{*}{ Soil classification } \\
\hline & & & & a & $\%$ & \\
\hline $1 \mathrm{Ac}$ & $0-1$ & $>150$ & $\mathrm{C}$ & 12,17 & 45.3 & Molli \\
\hline $1 \mathrm{Bc}$ & 1 & $100-150$ & $\mathrm{C}$ & 52 & 9.6 & Mo \\
\hline $1 \mathrm{Ecl}$ & $0-1$ & $<30$ & $\mathrm{CL}$ & 3,677 & 13.8 & Mollic Leptosols \\
\hline $2 \mathrm{Cc}$ & -2 & $50-100$ & $\mathrm{C}$ & 7,698 & 28.8 & Vertic Luvisols \\
\hline $3 \mathrm{Ccl}$ & $2-5$ & $50-100$ & $\mathrm{CL}$ & 674 & 2.5 & Haplic Cambisols \\
\hline
\end{tabular}

$\mathrm{C}=$ Clay; $\mathrm{CL}=$ Clay loam

\subsection{Suitability Analysis and Mapping}

The physical irrigation suitability analysis was carried out following FAO method for general irrigation farming [15]. The suitability was carried out by matching the LMUs topographic characteristics and soil properties with factor ratings table of the class determining factors [16]. The irrigation suitability evaluation were presented as S1 (highly suitable), S2 (moderately suitable), S3 (marginally suitable) and $\mathrm{N}$ (non suitable). The ArcGIS 9.3 was employed for mapping the physical irrigation suitability of the study area.

\section{Results and Discussion}

\subsection{Characteristics of the Study Area}

The topographic characteristics and the soil properties showed variation across the study area. Particle size analysis result showed that $\mathrm{LMU} 1 \mathrm{El}$ and $3 \mathrm{Cl}$ were texturally clay loam where as the rest of the LMUs were texturally clay (Table 3). The slope ranges of all the LMUs were included under highly suitable category, except for LMU $3 \mathrm{Cl}$, which was categorized under moderately suitable for irrigation. Considering drainage condition, most of the LMUs were well drained, except LMU $1 \mathrm{Ac}$ and $1 \mathrm{Bc}$, which were imperfectly and moderately well drained.

On the other hand, surface stoniness, surface coarse fragments, subsurface coarse fragments and rockiness were almost none in most of the LMUs. However, substantial amount of subsurface coarse fragments were observed in LMU 2Cc, $1 \mathrm{El}$ and $3 \mathrm{Cc}$ (Table 3). With regards to lime, gypsum, EC and ESP contents, the values were trace to low. 
Table 3. Soil description and analysis results of soils of Abobo area.

\begin{tabular}{llllll}
\hline \multirow{2}{*}{ Parameters } & \multicolumn{7}{l}{ Land mapping unit } \\
\cline { 2 - 7 } & 1Ac & 1Bc & 1Ecl & 2Cc & 3Ccl \\
\hline Slope (\%) & $0-1$ & $0-1$ & $0-1$ & $1-2$ & $2-5$ \\
Drainage & ID & MWD & WD & WD & WD \\
Top soil texture (0-25cm) & Clay & Clay & CL & Clay & CL \\
Sub soil texture (25-100 cm) & Clay & Clay & - & Clay & CL \\
Surface stoniness (\%) & N & N & N & N & N \\
Surface fragments (0-25 cm) (\%) & N & N & N & N & N \\
Subsurface fragments (\%) & N & N & 86 & 21 & 27 \\
Rockiness (\%) & N & N & N & N & N \\
Depth to solid rock (m) & $>2$ & $>2$ & 0.5 & 1.5 & 1.5 \\
Lime content (\%) & 0.25 & 0.2 & 0.3 & 0.2 & 0.25 \\
Gypsum content (\%) & Trace & Trace & Trace & Trace & Trace \\
EC mmhos/cm (average 0-100cm) & 0.15 & 0.15 & 0.15 & 0.15 & 0.15 \\
ESP (\%) (maximum 0-100 cm) & 0.45 & 0.5 & 0.35 & 0.35 & 0.55 \\
\hline
\end{tabular}

$\mathrm{ID}=$ Imperfectly drained; $\mathrm{WD}=$ Well drained; $\mathrm{MWD}=$ Moderately well drained; $\mathrm{CL}=$ Clay loam; $\mathrm{N}=$ None

\subsection{Physical Land Suitability Evaluation for Irrigation}

Physical Irrigation suitability evaluation for lower Alwero river area is presented in Table 4. The result showed that LMU $1 \mathrm{Ac}, 1 \mathrm{Bc}$ and $2 \mathrm{Cc}$, with total area of $22,367.9$ ha $(83.7 \%)$, were moderately suitable (S2). The moderate limiting factors were drainage, top soil texture and subsoil texture. It was found that LMU $1 \mathrm{Ecl}$, covering an area of $3,677.6$ ha $(13.8 \%)$ were not suitable $(\mathrm{N})$ for irrigation due to subsurface coarse fragments and depth to solid rock or hardpan. On the other hand, LMU $3 \mathrm{Ccl}$ with an area of 674.4 ha $(2.5 \%)$ was marginally suitable (S3) for irrigation. The most limiting factor in using irrigation in this LMU would be subsurface coarse fragments; slope also has moderate limitation for this LMU. For all LMUs, parameters like lime, gypsum, EC and ESP were not considered as limiting factors. However, salinity and alkalinity were reported as main limiting factors for irrigation suitability elsewhere [5, 17-20].

Table 4. Irrigation suitability evaluation for lower Alwero river area.

\begin{tabular}{llllll}
\hline \multirow{2}{*}{ Class determining factors } & \multicolumn{5}{l}{ Land mapping unit } \\
\cline { 2 - 6 } & 1Ac & 1Bc & 1El & 2Cc & 3Cl \\
\hline Slope (\%) & S1 & S1 & S1 & S1 & S2 \\
Drainage & S2 & S2 & S1 & S1 & S1 \\
Top soil texture (0-25cm) & S2 & S2 & S1 & S2 & S1 \\
Sub soil texture (25-100 cm) & S2 & S2 & S1 & S2 & S1 \\
Surface stoniness (\%) & S1 & S1 & S1 & S1 & S1 \\
Surface fragments (0-25 cm) (\%) & S1 & S1 & S1 & S1 & S1 \\
Subsurface fragments (\%) & S1 & S1 & N & S2 & S3 \\
Rockiness (\%) & S1 & S1 & S1 & S1 & S1 \\
Depth to solid rock (m) & S1 & S1 & N & S2 & S2 \\
Lime content (\%) & S1 & S1 & S1 & S1 & S1 \\
Gypsum content (\%) & S1 & S1 & S1 & S1 & S1 \\
EC mmhos/cm (average 0-100cm) & S1 & S1 & S1 & S1 & S1 \\
ESP (\%) (maximum 0-100 cm) & S1 & S1 & S1 & S1 & S1 \\
Over all suitability & S2 & S2 & N & S2 & S3 \\
\hline
\end{tabular}

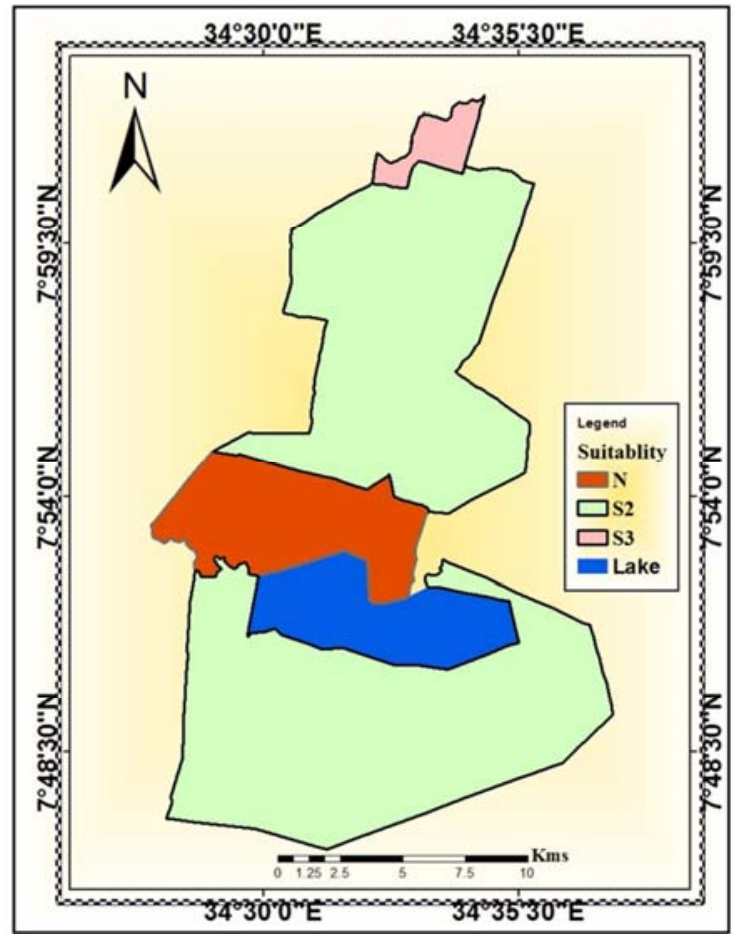

Figure 3. Physical land suitability evaluation map for Irrigation in the lower Alwero river area of Abobo, western, Ethiopia.

\section{Conclusion}

In this study, the physical irrigation suitability of five LMUs was assessed in the lower Alwero river area of Abobo, western Ethiopia. The result revealed that about $83.7 \%$ and $2.5 \%$ of the study area was moderately (S2) and marginally suitable (S3) for irrigation, respectively; drainage, top soil texture and subsoil texture being the moderately limiting factors. The remaining $14 \%$ of the area was not suitable for irrigation due to shallow soil depth.

\section{Acknowledgements}

The authors would like to thank the Gambella Agricultural Technical Vocational Education and Training College for their financial support. The staffs of Addis Ababa National Soil Testing Laboratory are greatly acknowledged for their cooperation during soil analysis.

\section{References}

[1] M. Albaji, A. Landi, B. S. Nasa and K. Moravej, "Land suitability evaluation for surface and drip irrigation in Shavoor plain, Iran". Journal of Applied Science, 8(4): 654-659, 2008.

[2] R.MJ. Kadigi, Girmaye Tesfaye, A. Bizoza and Genet Zinabou, "Irrigation and water use efficiency in sub-Saharan Africa". GDN Agriculture Policy Series. Briefing paper number 4, 2012.

[3] T. Solomon, "Characterization and classification of soils, and irrigation suitability of the land in Sheneka, Bale Zone". MSc thesis, Haramaya Uiniversity, Ethiopia, 2007. 
[4] O. Dengiz, "Comparison of different irrigation methods based on the parametric evaluation approach". Turk Journal of Agric For 30, 21-29, 2006.

[5] S. Ashraf and B. Normohammadan, "Comparing FAO methods to estimate wheat productivity potential in Damghan plain of Iran". World Applied Science Journal, 13(8): 1787-1792, 2011.

[6] D.G. Rossiter, "A theoretical framework for land evaluation (with Discussion)". Geoderma, 72, 165-202, 1996.

[7] S. V. Bobade, B.P. Bhaskar, M.S. Gaikwad, P. Raja, S.S. Gaikwad, S.G. Anantwar, S.V. Patil, S.R. Singh and A.K. Maji, "A GIS-based land use suitability assessment in Seoni District, Madhya Pradesh, India". Tropical Ecology, 51(1): 41-54, 2010.

[8] Ir. C.Sys, E. Van Ranst, Ir. J. Debaveye and F. Beernaert, "Land evaluation. Part II, principles in land evaluation and crop production calculations". Agricultural publications No. 7, 1991.

[9] B. Seleshi, D. Aster, L. Makonnen, W. Loiskandl, A. Mekonnen and A. Tena. "Water Resources and Irrigation Development in Ethiopia. Colombo, Sri Lanka: International Water Management Institute”. Working Paper 123, 2007.

[10] Yeshibir, Gambella People's Regional State land-use/land allotment study. Section 9, soils. Yeshibir Consult, Addis Ababa, Ethiopia, 2003.

[11] A. Davidson, Reconnaissance geology and geochemistry of Southwest Ethiopia. Ethiopian Institute of Geological Surveys, Addis Ababa, Ethiopia, 1983.

[12] WBISPP (Woody Biomass Investment Strategic Plan and Program), A Strategic Plan for the Sustainable Development, Conservation and Management of the Wood Biomass Resource. Gambella Regional State, Ethiopia, 2001.
[13] FAO (Food and Agriculture Organization of the United Nations), Guidelines: Land evaluation for irrigated agriculture. Soil bulletin 55, 1985.

[14] IUSS (International Union of Soil Science) Working Group, World Reference base for Soil Resources: A framework for international classification, correlation and communication. $2^{\text {nd }}$ Edition. World Soil Resources Reports No. 103. FAO, Rome, 2006.

[15] FAO (Food and Agriculture Organization of the United Nations), Land evaluation criteria for irrigation. World Soil Report, No 50, FAO, Rome, 1979.

[16] L.L. Resler, Irrigation suitability land classification: its application to land and water resources planning. FAO World Soils Resources Report, No 50, paper 4, 1979.

[17] A. A. Jafarzadeh, P. Alamdari, M. R. Neyshabouri and S. Saedi, "Land suitability evaluation of Bilverdy Research Station for wheat, barley, alfalfa, maize and safflower". Soil \& Water Research, 3, (Special Issue 1): S81-S88, 2008.

[18] M. Albaji, A.A. Naseri, P. Papan and S.B. Nasab, "Qualitative evaluation of land suitability for principal crops in the west Shoush pain, Southwest Iran. Bulgarian Journal of Agricultural Science, 15 (2): 135-145, 2009.

[19] S. Ashraf, "Land suitability evaluation for irrigated barley in Damghan plain, Iran”. Indian Journal of Science and Technology, 4(9): 1182-1187, 2011.

[20] Y. K. Kalkhajeh, H. Amerikhah and A. Landi, "Comparison of surface and drip irrigation methods based on the parametric evaluation approach in terms of FAO framework in Hendijan plain". Research Journal of Environmental and Earth Sciences, 4(3): 230-236, 2012. 